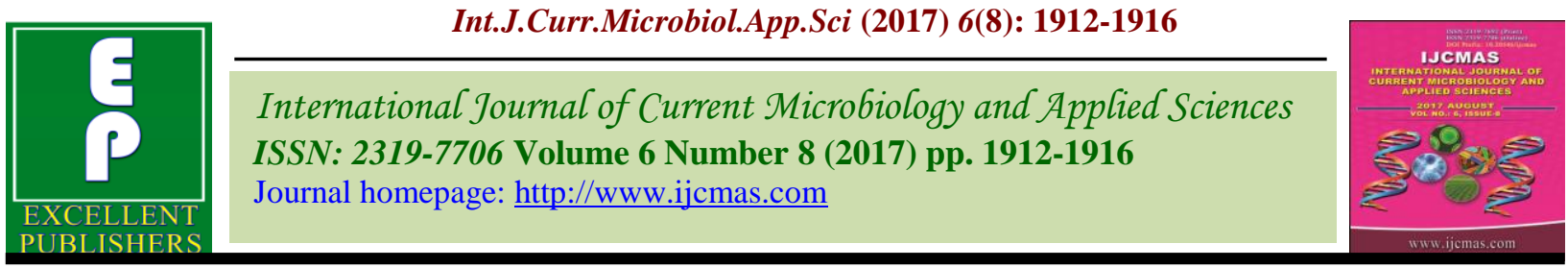

Original Research Article https://doi.org/10.20546/ijcmas.2017.608.225

\title{
Effect of Supplementation of Various Levels of Inulin on Immunity and Lymphoid Organs Weight in Raja II Broilers
}

\author{
T. Praveen, T. Munegowda, H.C. Indresh ${ }^{*}$ and Jayanaik \\ Department of Poultry Science, Veterinary College, KVAFSU, Bangalore, 560 024, India \\ *Corresponding author
}

A B S T R A C T

Keywords

Broiler, Antibody, Inulin and Immunity.

Article Info

Accepted:

19 June 2017

Available Online:

10 August 2017
A biological trial was conducted to study the effect of supplementing various levels of inulin on immunity and lymphoid organs weight in Raja II broilers from 1 to 42 days of age. 225 day old straight run Raja II broiler chicks were selected randomly and out of this 45chicks were assigned randomly to each treatment: control (without inulin), control +0.25 percent inulin $\left(\mathrm{T}_{2}\right)$, control +0.5 percent inulin $\left(\mathrm{T}_{3}\right)$, control +0.75 percent inulin $\left(\mathrm{T}_{4}\right)$ and control +1 percent inulin $\left(\mathrm{T}_{5}\right)$. The supplementation of various levels of inulin in broiler diets found effective in improving significantly antibody titre against IBDV, but not in NDV and also change in lymphoid organs weight. The results indicated that inulin have a better effect on antibody titre against IBD in broilers.

\section{Introduction}

Antibiotics have been widely used in animal production for many years. Although, some antibiotics are used therapeutically to improve the health and well-being of animal a large portion was employed for prophylactic purposes and to improve growth performance.

The long-term presence of antibiotics in the microbial population has made antibiotics in the microbial population has made antibioticresistant strains by gene mutation more efficient in survival compared to normal microbes (Murray and Moellering, 1978). However due to the emergence of microbes resistant to antibiotics which are used to treat human and animal infection, antibiotics are being taken out of poultry diets around the world. The immune system highly depends on an adequate supply of nutrients to function properly. Besides the essential nutrients, nonessential food constituents such as nondigestible carbohydrates may also have an impact on the immune system (Seifert and Watzl, 2007).

Prebiotics cause potential possibilities of their practical using in non- specific immune prophylaxis lots of animal diseases. The ban placed on using antibiotic growth promoters raised an interest in prebiotics as alternative solution in poultry farms. Commercially available prebiotics are mostly fructooligosaccharides, isomalto-oligosaccharides, inulin, raffinose, lactulose, malto- 
oligosaccharides, guar gum, sucrose thermal oligosaccharides, galacto-oligosaccharides, transgalacto-oilgosaccharides, xylooligosaccharide.

Inulin contains oligosaccharides components and polysaccharides. Because of the $\beta$ (2-1) glycosidic bond, it is resistant to host derived digestive enzymes and is believed to enhance the growth of health-promoting bacteria and to suppress the growth of potential pathogenic bacteria. By promoting the growth of lactic acid producing bacteria, prebiotics have an indirect beneficial effect on the immune system of the host. These bacterial populations produce immune stimulating substances that react with the immune system at different levels, including the production of cytokines, mononuclear cells and macrophage phagocytosis as well as the induction of synthesis of large amounts of Ig, particularly IgA (Yasui and Ohwaki, 1991; Macfarlance and Cummings, 1999). Moreover, consumption of inulin- type fructans could be one way to modulate mucosa-associated biofilms so that members of the biofilm community, generally considered as health- promoting, are stimulated (Kleessen and Blaut, 2005).It is believed that inulin enhanced with oligofructose $(\mathrm{OF})$ causes beneficial changes in the immune function of GALT (Roller et al., 2004). Hence, this study was designed to study the effect of various levels of inulin with the immuno competence and lymphoid organs weight inn Raja II broilers.

\section{Materials and Methods}

\section{Experimental design and diets}

A total of 225 day old straight run Raja II broiler chicks were wing banded, weighed and randomly assigned to five treatment groups with three replicates in each treatment group and with 15 chicks in each replicate consisting of five dietary treatments: control (without inulin), control +0.25 percent inulin $\left(\mathrm{T}_{2}\right)$, control +0.5 percent inulin $\left(\mathrm{T}_{3}\right)$, control +0.75 percent inulin $\left(\mathrm{T}_{4}\right)$ and control +1 percent inulin $\left(T_{5}\right)$. The chicks were reared under deep litter system with all standard managemental practices till 6 weeks of age. Standard vaccination schedule were followed for immunizing the chicks. Birds were fed with broiler pre starter diet (0-7 days), starter diet (8-21 days) and finisher diet (22-42 days).The basal diet was formulated as per the specifications of BIS-2007. Inulin sample required for the trial was procured from Quadragen Vet health Private Limited, Bangalore.

\section{Immuno competence}

\section{HI titer against new castle disease virus}

The micro-test method described by Allan and Gouch (1974) was used for detection of HI titers from serum samples collected on $42^{\text {nd }}$ day of post immunization of birds to assess the antibody titers. The HI test was done manually by $\beta$ - procedure in ' $U$ ' bottom micro-plates using diluters, droppers and 4 HA units of ND viral antigen. Serial two fold dilution of serum in normal saline was taken and $25 \mu \mathrm{l} /$ well $4 \mathrm{HA}$ unit of antigen was added. Plates were incubated for 45 minutes at room temperature. Fifty $\mu 1$ of 0.8 per cent chicken erythrocytes were added to each well and the plates were incubated for one hour at room temperature before reading the results. The titers were expressed as the reciprocal of highest dilution of serum showing the haemagglutination inhibition or button formation.

\section{Antibody titer against infectious bursal disease virus}

The serum antibodies against IBDV were titered by using Poultry Diagnostic and Research Centre (PDRC) indirect ELISA Kit. Each of the steps was followed as per the 
manufacturer's instructions. Each of the wells of antigen pre-coated plate provided in the kit was used for the test.100 $\mu \mathrm{L}$ each of the positive control serum and the negative control serum were added in duplicates to the respective control wells. Then, $100 \mu \mathrm{L}$ of each test serum sample diluted in the sample buffer were added in duplicates to corresponding wells of the plate (apart from the control wells) and incubated at $37{ }^{\circ} \mathrm{C}$ for one hour. The plate was washed using the wash buffer provided in the kit. One hundred $\mu \mathrm{L}$ of mouse anti-chicken $\operatorname{IgG}$ conjugated with Horse Raddish Peroxidase (HRP) in wash buffer was added to each of the wells and incubated at $37^{\circ} \mathrm{C}$ for one hr. The plate was washed as before mentioned. One hundred $\mu \mathrm{L}$ of freshly prepared chromogensubstrate solution containing OPD and 3\% $\mathrm{H}_{2} \mathrm{O}_{2}$ as substrate (4 $\mathrm{L} / \mathrm{ml}$ of chromogen) were added to each of the wells and the plate was kept at room temperature for $15 \mathrm{~min}$. Finally, $50 \mu \mathrm{L}$ of $2.5 \mathrm{~N}$ HCL was added to each of the wells to stop enzyme-substrate reaction. Absorbance values were read using the ELISA reader (Bio Rad) with an interference filter at $492 \mathrm{~nm}$. Readings were taken after the wells with only substratechromogen and HCL were blanked to 'zero' at $492 \mathrm{~nm}$.

\section{Lymphoid organs weight}

The weight of lymphoid organs such as spleen, bursa of fabricius and thymus was taken on $42^{\text {nd }}$ day of the experiment during the slaughter of the birds and expressed as per cent of live body weight.

\section{Results and Discussion}

The results of the current study evaluating the effect of various levels of inulin in Raja II broilers on immune response for ND and IBD vaccination showed that there was no significant $(\mathrm{P}>0.05)$ difference in titer value against NDV and significant $(\mathrm{P} \leq 0.05)$ difference in titer value against IBDV among different treatment groups presented in table 1. This is in agreement with the findings of Elrayehand Yildiz (2012) conducted an experiment with Ross broilers fed $0.7 \%$ inulin for 6 week in which the antibody titer against ND viruses was investigated on 26 day and at the end of the experimental period showed non-significant difference. Sadeghi et al., (2013) reported that dietary inclusion of prebiotics had no significant differences in antibody titers against ND viruses at 21 and 42 days of age.

But results of the present experiment are in contrary with the finding of Saeed et al., (2015) revealed that addition of different levels of chicory leaf extract $(5,10$ and 15 $\mathrm{ml} / \mathrm{L}$ ) in drinking water exhibited significant effect $(\mathrm{P}<0.05)$ on ND titer and unaffected $(\mathrm{P}>0.05)$ against infectious bursal disease (IBD) in broilers.

Table.1 Effect of supplementation of inulin on antibody titer against New Castles Disease (NDV) and Infectious Bursal Disease Virus (IBDV) of Raja II broilers

\begin{tabular}{|c|c|c|c|}
\hline Experimental group & Description of the treatment & NDV log HI titer & IBDV titer (ELISA) \\
\hline $\mathrm{T}_{1}$ & Control (without Inulin) & $0.90 \pm 0.30$ & $1359.0 \pm 288.3^{\mathrm{a}}$ \\
\hline $\mathrm{T}_{2}$ & Control + 0.25\%Inulin & $0.93 \pm 0.16$ & $1762.0 \pm 163.8^{\mathrm{ab}}$ \\
\hline $\mathrm{T}_{3}$ & Control + 0.5\%Inulin & $0.74 \pm 0.10$ & $2084.6 \pm 359.7^{\mathrm{ab}}$ \\
\hline $\mathrm{T}_{4}$ & Control+ 0.75\% Inulin & $0.94 \pm 0.21$ & $1851.8 \pm 231.0^{\mathrm{ab}}$ \\
\hline $\mathrm{T}_{5}$ & Control + 1\% Inulin & $0.78 \pm 0.12$ & $2413.0 \pm 291.4^{\mathrm{b}}$ \\
\hline
\end{tabular}

Means bearing different superscript column wise differ significantly $(\mathrm{P} \leq 0.05)$ 
Table.2 Effect of supplementation of inulin on lymphoid organs weight ( $\mathrm{g} / 100 \mathrm{~g}$ body weight) of Raja II broilers

\begin{tabular}{|c|c|c|c|c|}
\hline \multirow{2}{*}{$\begin{array}{c}\text { Experimental } \\
\text { group }\end{array}$} & $\begin{array}{c}\text { Description of } \\
\text { the treatment }\end{array}$ & \multicolumn{3}{|c|}{ Lymphoid organs weight (g/100g body weight) } \\
\cline { 3 - 4 } & Spleen & Bursa of Fabricius & Thymus \\
\hline $\mathrm{T}_{1}$ & Control (without Inulin) & $0.15 \pm 0.01$ & $0.10 \pm 0.01$ & $0.35 \pm 0.02$ \\
\hline $\mathrm{T}_{2}$ & Control + 0.25\%Inulin & $0.19 \pm 0.01$ & $0.09 \pm 0.01$ & $0.42 \pm 0.04$ \\
\hline $\mathrm{T}_{3}$ & Control + 0.5\%Inulin & $0.16 \pm 0.01$ & $0.13 \pm 0.01$ & $0.43 \pm 0.01$ \\
\hline $\mathrm{T}_{4}$ & Control+ 0.75\% Inulin & $0.14 \pm 0.01$ & $0.12 \pm 0.01$ & $0.44 \pm 0.05$ \\
\hline $\mathrm{T}_{5}$ & Control + 1\% Inulin & $0.18 \pm 0.02$ & $0.04 \pm 0.01$ & $0.39 \pm 0.01$ \\
\hline
\end{tabular}

The higher level of antibody titer against IBDV in birds using chicory leaf extractinulin may be due to its antimicrobial effect. Another possible reason might be the increased activity of neutrophils in blood after vaccination, which could play a major role to boost up the immunity (Guo et al., 2003).

The results of this study on lymphoid organs weight revealed that there was no significant difference in relative weights of lymphoid organs viz., spleen, bursa of fabricius and thymus presented in table 2 and this result is in agreement with the findings of Nabizadeh et al., (2012) reported that $0.5 \%$ and $1 \%$ inulin inclusion had no significant effect on relative weight of thymus and spleen at the end of the grower and finisher period and bursa of fabricius weight at grower period. The lack of effect on immunological organs weights might be due to the production of $\mathrm{Ig}$ and lymphocytes was not increased with dietary inulin supplementation. This may be due to a lack of challenge, as the birds were used in this trail and thus more isolated from pathogen presence than in a production houses.

\section{Acknowledgements}

The authors acknowledge the research facilities provided by the Karnataka Veterinary, Animal and Fisheries Sciences University, Bidar, India, for conducting this study.

\section{References}

Elrayeh, A. S. and Yildiz, G., 2012.Effects of inulin and $\beta$-glucan supplementation in broiler diets on growth performance, serum cholesterol, intestinal length, and immune system. Turkey J. Vet. Anim. Sci., 36(4): 388-394

Guo, Y., Ali Ra and Qureshi, M.A., 2003. The influence of $\beta$ - glucan on immune responses in broiler chicks. $J$. Immunopharmacol, 25: 461-472

Kleessen, B. and Blaut, M., 2005.Modulation of gut mucosal bio films. British $J$. Nutr., 93(1): 35-40

Macfarlance, G.T. and Cummings, J.H., 1999. Probiotics and prebiotics: Can regulating the activities of intestinal bacteria benefit health? BMJ, 318:9991003

Murray, B.E. and Moellering JR, R.C., 1978. Patterns and mechanisms of antibiotic resistance. Med. Clin. N. Am., 63:899923

Nabizadeh, A., Gevorkyan, O. and Golian, A., 2012.Effect of inulin on some hematological, immunological parameters and broiler chickens performance. J. Anim. Vet. Adv., 11(18): 3304-3311

Roller, M., Rechkemmer, G. and Watzl, B., 2004. Prebiotic inulin enriched with oligofructose in combination with the probiotics Lactobacillus rhamnosus and Bifidobacterium lactis modulates intestinal immune functions in rats. $J$. 
Nutr., 134: 153-156

Sadeghi, A. S., Mohammadi, A., Shawrang, P. and Aminafshar, M., 2013.Immune responses to dietary inclusion of prebiotic-based mannan-oligosaccharide and $\beta$-glucan in broiler chicks challenged with Salmonella enteritidis. Turkey J. Vet. Anim. Sci., 37 (2): 206213

Saeed, M., Baloch, A.R., Wang, M., Soomro, R.N., Baloch, A.M., Bux, B.A., Arian, M.A., Faraz, S.S. and Zakriya, H.M., 2015. Use of Cichorium intybus leaf extract as growth promoter, hepatoprotectant and Immune modulent in broilers. J. Anim. Prod. Adv, 5(1): 585-591

Seifert, S. and Watzl, B., 2007. Inulin and oligofructose: Review of experimental data on immune modulation. J. Nutr. 137:2563S-2567S

Yasui, H. and Ohwaki, M., 1991. Enhancement of immune response in payer's patch cells cultured with Bifidobacterium breve. J. Dairy Sci., 74:1187-1195

\section{How to cite this article:}

Praveen, T., T. Munegowda, H.C. Indresh and Jayanaik. 2017. Effect of Supplementation of Various Levels of Inulin on Immunity and Lymphoid Organs Weight in Raja II Broilers. Int.J.Curr.Microbiol.App.Sci. 6(8): 1912-1916. doi: https://doi.org/10.20546/ijcmas.2017.608.225 